\title{
The Relationship between the Infant Gut Microbiota and Allergy. The Role of Bifidobacterium breve and Prebiotic Oligosaccharides in the Activation of Anti-Allergic Mechanisms in Early Life
}

\author{
Bożena Cukrowska ${ }^{1, *}$, Joanna B. Bierła ${ }^{1}{ }^{(}$, Magdalena Zakrzewska ${ }^{2}$, Mark Klukowski ${ }^{3}\left({ }^{\circledR}\right.$ and \\ Elżbieta Maciorkowska ${ }^{2,3}$ \\ 1 Department of Pathology, The Children Memorial Health Institute, Aleja Dzieci Polskich 20, 04-730 Warsaw, \\ Poland; j.bierla@ipczd.pl \\ 2 Department of Developmental Age Medicine and Paediatric Nursing, Faculty of Health Sciences, Medical \\ University of Bialystok, Szpitalna St. 37, 15-295 Białystok, Poland; magdalena.maciorkowska@com.pl (M.Z.); \\ emaciorkowska@o2.pl (E.M.) \\ 3 Department of Pediatrics and Pulmonary Diseases, Faculty of Health Sciences, Medical University of \\ Bialystok, Jerzego Waszyngtona St. 17, 15-274 Białystok, Poland; mark.klukowski@gmail.com \\ * Correspondence: b.cukrowska@ipczd.pl; Tel.: +48-22-815-19-69
}

Received: 27 February 2020; Accepted: 26 March 2020; Published: 29 March 2020

check for updates

\begin{abstract}
The increase in allergy prevalence observed in recent decades may be a consequence of early intestinal dysbiosis. The intestinal microbiota is formed in the first 1000 days of life, when it is particularly sensitive to various factors, such as the composition of the mother's microbiota, type of delivery, infant's diet, number of siblings, contact with animals, and antibiotic therapy. Breastfeeding and vaginal birth favorably affect the formation of an infant's intestinal microbiota and protect against allergy development. The intestinal microbiota of these infants is characterized by an early dominance of Bifidobacterium, which may have a significant impact on the development of immune tolerance. Bifidobacterium breve is a species commonly isolated from the intestines of healthy breastfed infants and from human milk. This review outlines the most important environmental factors affecting microbiota formation and the importance of Bifidobacterium species (with a particular emphasis on Bifidobacterium breve) in microbiota modulation towards anti-allergic processes. In addition, we present the concept, which assumes that infant formulas containing specific probiotic Bifidobacterium breve strains and prebiotic oligosaccharides may be useful in allergy management in non-breastfed infants.
\end{abstract}

Keywords: microbiota; gut; allergy; prevention; synbiotics; Bifidobacterium breve

\section{Introduction}

Allergic diseases are one of the leading medical challenges in highly developed countries, where the proportion of affected individuals may already exceed $30 \%$ and is constantly rising [1,2]. The rise in allergy prevalence may be associated with the so-called 'western lifestyle': improved hygiene, frequent use of antibiotics, reduced family size, altered eating habits (consumption of highly processed foods), general urbanization, and limited contact with nature [3,4]. Not without significance is also the growing number of Caesarean sections (C-sections), which correlates with an increased incidence of food allergy (FA) and asthma [5,6]. All these factors, which are associated with progressive development of societies and increase the risk of allergies, also greatly affect the intestinal microbiota-currently considered to be a 'super organ', necessary for the proper functioning of the immune system and the development of immune tolerance [7]. The microbiota hypothesis of allergy development assumes that the microbiota 
programs the baby's immature immune system, which affects their health in later years, and the increase in allergy prevalence may be a consequence of intestinal dysbiosis during the first months of life [8]. In this review, we discuss the most important environmental factors affecting early microbiota composition and the importance of bifidobacteria, with a particular emphasis on Bifidobacterium breve strains, in immune-system modulation towards anti-allergic processes. We also present the concept which assumes that infant formulas containing a combination of specific probiotic Bifidobacterium breve strains and prebiotic oligosaccharides may be useful in allergy management in non-breastfed infants.

\section{Intestinal Microbiota Formation and Dysbiosis-Inducing Factors}

It is currently accepted that the intestinal microbiota begins developing right after birth, but there are studies suggesting that microbiota formation may start in the pre-natal period $[9,10]$. During vaginal delivery, the mother's microbiota is the main source of microorganisms colonizing newborns [11,12]. Bifidobacterium spp. appear in breastfed newborns already on the 2nd day of life, and by the second week, they become the predominant bacterial genus in the gastrointestinal tract. The predominance of Bifidobacterium spp. persists until solid foods are introduced into the diet and the baby is weaned off breast milk [13]. Expanding the diet causes an increase in the number of bacteria from the Bacteroidetes and Firmicutes phyla. By the age of approximately $2-3$ years, the baby's microbiota is stabilized, and its composition resembles that of adults' microbiota, with predominance of Bacteroidetes [14,15]. This natural development of gut microbiota is often disturbed by C-sections, formula feeding, and antibiotic therapy [16-18]-i.e., dysbiosis-inducing factors that correlate with an increased risk of allergies.

\subsection{Cesarean Sections, the Microbiota, and Allergy Development}

Newborns born by C-section are deprived of exposure to the mother's microbiota, which results in a dysbiosis observable already in the first days of life [13]. The intestinal microbiota of these neonates appears to be less diverse, in terms of bacterial species, than the microbiota of vaginally-delivered babies [19]. Moreover, unlike in vaginally-born newborns, bifidobacteria are still absent in C-section babies at the age of 3 days, despite breastfeeding [13]. Stools of C-section babies show reduced numbers of Escherichia coli and Bacteroides, with increased numbers of Clostridium difficile [20], and may harbor potentially pathogenic bacteria, such as Klebsiella, Enterococcus, and Clostridium [12,13,19].

The results of our study showed that C-section deliveries also influence the microbiota of babies born prematurely [21]. The intestinal microbiome of pre-term C-section babies, in comparison with vaginally-born pre-term newborns, showed a lack of Bacteroides in the first 8 days of life, and this status remained unchanged for the entire follow-up period of 8 weeks. Other researchers also point out that gut microbial dysbiosis associated with C-sections results in long-lasting disturbances of microbiota homeostasis [17]. Reduced biodiversity of microbiota, with a lower abundance of Bacteroidetes in C-section-delivered babies, was demonstrated to persist at least until the age of 2 years, i.e., until microbiota development has been completed [20]. Interestingly, analysis of peripheral blood cytokine profiles in these infants showed an imbalance in pro-inflammatory Thelper type 1 (Th1) and pro-allergic T helper type 2 (Th2) cells. Infants born through C-section had significantly lower levels of the Th1-associated chemokines CXCL10 and CXCL11, which directed their immune response towards pro-allergic Th2-mediated reactions.

Epidemiological studies have confirmed that Cesarean births correlate with an increased incidence of FA and asthma [5,6,22-24]. The latest American cohort study in children born in the state of New York ( $n=1356)$ in the years 2008-2010 showed that emergency C-section delivery was associated with a higher relative risk ( $R R)$ of wheezing ( $R R=2.47,95 \% \mathrm{CI} 1.31-4.66)$ and FA ( $R R=3.02,95 \% \mathrm{CI}$ 1.26-7.25) [22]. A cohort study conducted by Wu et al. in 136,098 children showed that the risk of developing asthma in 4.5-6-year-old children with multiple risk factors, including C-section, increased more than sevenfold [25]. The odd ratio (OR) was 7.77 (95\% CI 6.25-9.65), when, in addition to cesarean delivery, there were also other factors adversely affecting the intestinal microbiota, such as maternal and infant exposure to antibiotics, as well as a lack of siblings at home [26]. 


\subsection{Antibiotics, Microbiota, and Allergy Development}

Exposure to antibiotics is another important factor that shapes the intestinal microbiota. In the short term, antibiotic-induced changes in the intestinal microbiota may contribute to the pathogenesis of necrotizing enterocolitis (NEC) and antibiotic-associated diarrhea [27,28]. In the long term, antibiotic therapy in infants and young children may have a significant impact on the process of microbiota development and on microbial programming of anti-allergic mechanisms later in life $[29,30]$. Table 1 presents a summary of studies showing the effect of antibiotic exposure in perinatal and early post-natal periods on the composition of intestinal microbiota [26,31-38]. Studies in children from the age of 0 to 3 years showed that the microbiota of antibiotic-treated children was less diverse, with a lower abundance of the phylum Actinobacteria (with the genus Bifidobacterium), the genus Lactobacillus, Bacteroides, and had fewer stable bacterial communities in comparison with that in untreated children [38].

Table 1. Summary of studies demonstrating the effects of antibiotic treatment in the pre-natal period and early post-natal life on the gut microbiota.

\begin{tabular}{|c|c|c|c|c|c|}
\hline Age of Exposure to Antibiotics & $\begin{array}{c}\text { Age at } \\
\text { Evaluation }\end{array}$ & Study Description & Type of Antibiotics & Effects on Microbiota & References \\
\hline $\begin{array}{l}\text { Prenatal (maternal intrapartum } \\
\text { antibiotic prophylaxis for Group } \\
\text { B Streptococcus or C-sections) }\end{array}$ & $\begin{array}{l}3,12 \text { months } \\
\text { after birth }\end{array}$ & Term infants $(n=198)$ & Cefazolin, penicillin & $\begin{array}{c}\downarrow \text { the genus Bacteroides and } \\
\text { Parabacteroides; } \\
\uparrow \text { Enterococcus and Clostridium; } \\
\text { differences persisted } 1 \text { year after birth } \\
\text { in infants with emergency C-sections }\end{array}$ & $\begin{array}{l}\text { Azad et al. } \\
(2016)[30]\end{array}$ \\
\hline $\begin{array}{l}\text { Prenatal (maternal intrapartum } \\
\text { antibiotic prophylaxis for Group } \\
\text { B Streptococcus) }\end{array}$ & $\begin{array}{l}10,30,90 \text { days } \\
\text { after birth }\end{array}$ & Term infants $(n=40)$ & Penicillin & $\begin{array}{c}\downarrow \text { the phylum Actinobacteria and } \\
\text { Bacteroidetes after } 10 \text { days; } \\
\uparrow \text { the phylum Firmicutes after } 10 \text { and } 90 \\
\text { days }\end{array}$ & $\begin{array}{l}\text { Nogacka et al. } \\
\text { (2017) [31] }\end{array}$ \\
\hline The first 2 days of life & $\begin{array}{l}4,8 \text { weeks after } \\
\text { finishing } \\
\text { antibiotic } \\
\text { treatment }\end{array}$ & Term infants $(n=18)$ & $\begin{array}{l}\text { Ampicillin, } \\
\text { gentamycin }\end{array}$ & $\begin{array}{c}\uparrow \text { the phylum Proteobacteria } \\
\downarrow \text { the phylum Actinobacteria } \\
\downarrow \text { the genus Bifidobacterium and } \\
\text { Lactobacillus after } 4 \text { weeks } \\
\uparrow \text { the phylum Proteobacteria } \\
\uparrow \text { the family Enterobacteriaceae and } \uparrow \text { the } \\
\text { genus Clostridium after } 8 \text { weeks }\end{array}$ & $\begin{array}{l}\text { Fouthy et al. } \\
\text { (2012) [32] }\end{array}$ \\
\hline The first 4 days of life & $\begin{array}{l}5 \text { days, } 1,2 \\
\text { months after } \\
\text { birth }\end{array}$ & Term infants $(n=26)$ & $\begin{array}{l}\text { Broad-spectrum } \\
\text { antibiotics }\end{array}$ & $\begin{array}{c}\downarrow \text { diversity of Bifidobacterium and } \\
\uparrow \text { Enterococcus after } 5 \text { days } \\
\uparrow \text { Enterobacteriaceae after } 1 \text { and } 2 \text { months }\end{array}$ & $\begin{array}{l}\text { Tanaka et al. } \\
(2009)[33]\end{array}$ \\
\hline The first 7 days of life & $\begin{array}{l}7 \text { days, } 1,3 \\
\text { months after } \\
\text { birth }\end{array}$ & $\begin{array}{l}\text { Term infants vaginally } \\
\text { born and breastfed ( } n \\
\quad=45)\end{array}$ & $\begin{array}{c}\text { Penicillin, } \\
\text { amoxicillin/clavulamic } \\
\text { acid, gentamycin, } \\
\text { cefdazidine }\end{array}$ & $\begin{array}{l}\text { \the phylum Bacteroidetes at all time } \\
\text { points } \\
\text { A delay in Bacteroidetes colonization } \\
\text { persisted for } 3 \text { months }\end{array}$ & $\begin{array}{c}\text { Eck et al. (2020) } \\
\text { [34] }\end{array}$ \\
\hline The first 7 days of life & $\begin{array}{l}1,2,3 \text { weeks } \\
\text { after birth }\end{array}$ & $\begin{array}{c}\text { Preterm infants } \leq 32 \\
\text { weeks gestational age } \\
(n=74)\end{array}$ & $\begin{array}{l}\text { Ampicillin and } \\
\text { gentamycin }\end{array}$ & $\begin{array}{l}\downarrow \text { diversity and } \uparrow \text { Enterobacter after } 2 \text { and } \\
\qquad 3 \text { weeks }\end{array}$ & $\begin{array}{l}\text { Greenwood et } \\
\text { al. (2014) [35] }\end{array}$ \\
\hline $\begin{array}{c}\text { Prenatal (maternal intrapartum } \\
\text { antibiotic prophylaxis for Group } \\
\text { B Streptococcus) and/or the first } 14 \\
\text { days of life }\end{array}$ & $\begin{array}{l}\text { 10, } 30,90 \text { days } \\
\text { after birth }\end{array}$ & $\begin{array}{l}\text { Very low birth weight } \\
\text { pre-term infants }\end{array}$ & $\begin{array}{l}\text { Penicillin, ampicillin, } \\
\text { ampicillin with } \\
\text { erythromycin }\end{array}$ & $\begin{array}{l}\text { } \text { the phylum Firmicutes and } \\
\text { Proteobacteria } \\
\downarrow \text { the phylum Actinobacteria after } 30 \text { days }\end{array}$ & $\begin{array}{l}\text { Arboleya et al. } \\
\text { (2015) [36] } \\
\text { Arboleya et al. } \\
\text { (2016) [37] }\end{array}$ \\
\hline The first 3 years of life & $\begin{array}{l}\text { Monthly } \\
\text { collection of } \\
\text { samples }\end{array}$ & $\begin{array}{l}\text { Term infants }(n=39) \\
\text { at } 2 \text { months of age } \\
\text { observed for } 3 \text { years } \\
(2-36 \text { months of life })\end{array}$ & $\begin{array}{l}\text { Different antibiotics } \\
(9-15 \text { antibiotic } \\
\text { courses in the first } 3 \\
\text { years of life) }\end{array}$ & $\begin{array}{l}\downarrow \text { diversity at the level of species and } \\
\text { strain } \\
\downarrow \text { Bacteroides } \\
\text { Less stable community and } \uparrow \text { antibiotic } \\
\text { resistance strains }\end{array}$ & $\begin{array}{l}\text { Yassour et al. } \\
\text { (2016) [38] }\end{array}$ \\
\hline
\end{tabular}

$\downarrow$-a decrease in bacteria counts or diversity; $\uparrow$-an increase in bacteria counts or antibiotic resistance.

The impact of antibiotic therapy on the risk of allergy development was very thoroughly discussed in a 2018 review by Obiakor et al. [28]. The authors emphasized that an increase in the use of antibiotics in the early period of development observed in highly developed societies correlates with an increase in allergy rates. A meta-analysis published in 2018 including 34 studies and 340,428 patients showed that exposure to antibiotics during the first 2 years of life was associated with an increased risk of hay fever, eczema, and FA later in life [39]. Other studies not evaluated in this meta-analysis presented in Table 2 showed that antibiotic therapy in early life is also associated with a higher risk of wheezing and asthma [40-47]. 
Table 2. Summary of studies demonstrating the impact of antibiotic exposure in the pre-natal period and early post-natal life on the risk of wheeze and asthma.

\begin{tabular}{|c|c|c|c|c|c|}
\hline Age of Exposure to Antibiotics & $\begin{array}{c}\text { Age at } \\
\text { Evaluation }\end{array}$ & Type of Study & Type of Antibiotics & Impact on the Risk of Allergy & References \\
\hline Prenatal (during pregnancy) & 3 years & $\begin{array}{l}\text { A retrospective cohort } \\
\text { study }\end{array}$ & Different antibiotics & $\begin{array}{l}\text { Tasthma, but only in children with } \\
\text { familial risk }\end{array}$ & $\begin{array}{l}\text { Lapin et al. } \\
\text { (2015) [40] }\end{array}$ \\
\hline Prenatal (during pregnancy) & Up to 5 years & $\begin{array}{l}\text { A prospective birth } \\
\text { cohort }\end{array}$ & $\begin{array}{l}\text { Antibiotics for } \\
\text { non-respiratory } \\
\text { infections }\end{array}$ & †asthma & $\begin{array}{l}\text { Stensballe et al. } \\
\text { (2013) [41] }\end{array}$ \\
\hline $\begin{array}{l}\text { Prenatal (during pregnancy) and } \\
\text { the first year of life }\end{array}$ & 3 and 6 years & A retrospective study & Different antibiotics & $\begin{array}{c}\text { Postnatal exposure- } \uparrow \text { asthma } \\
\text { Prenatal exposure- } \text { asthma only until } \\
\text { age } 3 \text { years }\end{array}$ & $\begin{array}{l}\text { Yoshida et al. } \\
\text { (2018) [42] }\end{array}$ \\
\hline Prenatal and the first year of life & $2-10$ years & $\begin{array}{l}\text { A population- and } \\
\text { register-based nested } \\
\text { case-control study }\end{array}$ & $\begin{array}{l}\text { Cephalosporins, } \\
\text { sulphonamides, } \\
\text { trimethoprim, } \\
\text { macrolides, } \\
\text { amoxicillin }\end{array}$ & †asthma & $\begin{array}{l}\text { Metsälä et al. } \\
(2015)[43]\end{array}$ \\
\hline Prenatal and the first year of life & Up to 7 years & $\begin{array}{c}\text { A nationwide } \\
\text { population based } \\
\text { study with sibling } \\
\text { analysis }\end{array}$ & Different antibiotics & $\begin{array}{l}\text { Tasthma when exposed to antibiotics } \\
\text { treating respiratory infections }\end{array}$ & $\begin{array}{l}\text { Ortqvist et al. } \\
\text { (2014) [44] }\end{array}$ \\
\hline The first 6 months of life & 2 years & A birth cohort study & Different antibiotics & $\begin{array}{l}\text { Twheezing, but not eczema and allergic } \\
\text { sensitization }\end{array}$ & $\begin{array}{l}\text { (Kummeling et } \\
\text { al.2007) [45] }\end{array}$ \\
\hline The first 6 months of life & 12 years & $\begin{array}{l}\text { A longitudinal cohort } \\
\text { study }\end{array}$ & Different antibiotics & Tatopic asthma & $\begin{array}{l}\text { Stromberg } \\
\text { Celind et al. } \\
(2018)[46]\end{array}$ \\
\hline The first 3 years of life & 15 years & A cohort study & Different antibiotics & asthma, but no asthma exacerbation & $\begin{array}{l}\text { Ahmadizar et } \\
\text { al. } 2017 \text { [47] }\end{array}$ \\
\hline
\end{tabular}

\subsection{Infant Diet, Microbiota, and Allergy Development}

Breast milk contains vast amounts of biologically active components that have a significant impact on the development of the gut microbiota [48]. Exclusively breastfed infants show a predominance of Bifidobacterium species in their intestines $[12,14]$. The microbiota of formula-fed infants is far more diverse, with a predominance of staphylococci, Bacteroides, clostridia, enterococci, enterobacteria, and generally lower numbers of Bifidobacterium and Lactobacillus species [12,15]. Bifidobacterium species can multiply in the intestines of breastfed infants due to the presence of unique human milk oligosaccharides (HMOs) [49]. HMOs are natural prebiotics that are resistant to digestive enzymes and when unchanged reach the large intestine, where they are a selective substrate for bifidobacteria [50]. Although HMOs are considered to be 'bifidogenic', it should be noted that only certain Bifidobacterium species, especially those present in the infant intestine, i.e., Bifidobacterium breve, Bifidobacterium longum subspecies infantis, and Bifidobacterium bifidum, have a high capacity for utilizing HMOs.

\subsubsection{Human Breast Milk-A Natural Synbiotic}

HMOs are not the only bioactive components that influence the formation of the intestinal microbiota [51]. Recent studies revealed that breast milk is not sterile and contains live probiotic Lactobacillus and Bifidobacterium species [52]. Apart from these two genera, Streptococcus and Staphylococcus are also present in human milk. The most commonly isolated Bifidobacterium species is Bifidobacterium breve and those of the genus Lactobacillus are Lactobacillus salivarius and Lactobacillus fermentum $[52,53]$.

It can therefore be stated that breast milk is a natural synbiotic, containing both probiotics and prebiotics [51]. The composition of breast milk microbiota, like that of the intestinal microbiota, depends on many factors: the composition of the mother's intestinal and skin microbiota, the state of her health, and exposure to medications, particularly antibiotics [54-61] (Table 3). 
Table 3. Maternal factors influencing the composition of breast milk microbiota.

\begin{tabular}{|c|c|c|}
\hline Factor & Microbiota Change & References \\
\hline Cesarean Section & $\begin{array}{c}\downarrow \text { Bifidobacterium } \\
\downarrow \text { Lactobacillus } \\
\downarrow \text { biodiversity } \\
\uparrow \text { Staphylococcus }\end{array}$ & $\begin{array}{l}\text { Khodayar-Pardo et al. (2014) [54] } \\
\text { Cabrera-Rubio et al. (2016) [55] }\end{array}$ \\
\hline Overweight and Obesity & $\begin{array}{c}\downarrow \text { Bifidobacterium } \\
\downarrow \text { biodiversity } \\
\uparrow \text { Staphylococcus }\end{array}$ & Collado et al. (2012) [56] \\
\hline Antibiotic Therapy & $\begin{array}{l}\downarrow \text { Bifidobacterium } \\
\downarrow \text { Lactobacillus }\end{array}$ & Soto et al. (2014) [57] \\
\hline Allergy & $\downarrow$ Bifidobacterium & Grönlund et al. (2007) [58] \\
\hline Celiac Disease & $\downarrow$ Bifidobacterium & Olivares et al. (2015) [59] \\
\hline
\end{tabular}

Antibiotic therapy during pregnancy and lactation drastically reduces Lactobacillus and Bifidobacterium counts in milk [54]. Studies have shown the complete absence of bifidobacteria in the breast milk of more than $50 \%$ of women who received antibiotics during pregnancy or lactation [54]. A significant decrease in diversity and the number of Bifidobacterium and Lactobacillus bacteria was also observed in the breast milk of women who gave birth via C-section, compared to that of women who gave birth vaginally $[55,56]$. The breast milk of obese mothers was also shown to contain lower numbers of bifidobacteria and higher numbers of Staphylococcus spp. and to demonstrate an altered immunomodulatory capacity associated with a decrease in the concentration of certain immunoregulatory proteins (e.g., growth transforming factor $\beta 2$ [TGF- $\beta 2$ ] and soluble CD14 molecules) [57].

\subsubsection{Human Milk and Allergy Prevention}

Despite the observed differences in the composition of breast milk, studies confirmed that breastfeeding protects the baby against the development of allergies. Exclusive breastfeeding for at least 3 months was shown to reduce the risk of developing atopic dermatitis (AD), even in genetically predisposed children [60]. An observational study in 3296 children (Canadian Healthy Infant Longitudinal Development Birth Cohort) showed that, in comparison to exclusive breastfeeding for the first 3 months of life, a different diet, such as formula-based feeding (OR $=2.14,95 \%$ CI 1.37-3.35) or breastfeeding with formula supplementation (OR $=1.73,95 \% \mathrm{CI} 1.17-2.57)$ increased the risk of developing asthma by the age of 3 years by about twofold [61].

Chu et al. attempted to answer the question of whether exclusive breastfeeding may decrease the risk of allergy in children born by C-section [62]. Their study confirmed that C-sections without medical indication were significantly associated with elevated risk of asthma at 6 years of age $(\mathrm{OR}=$ $1.58,95 \%$ CI 1.17-2.13). However, this risk was attenuated in children who were breastfed exclusively for the first six months of life (OR $=1.39,95 \% \mathrm{CI} 0.92-2.10)$. By contrast, the risk was more prominent in children with non-exclusive breastfeeding or formula feeding ( $\mathrm{OR}=1.91,95 \% \mathrm{CI} 1.22-2.99)$.

\section{Early Life Dysbiosis and Allergic Diseases}

The first 1000 days of life, which encompass both the pre- and post-natal periods of gut ecosystem formation, are the period of intestinal microbiota development. The intestinal microbiota is a new organ, which programs the immune system and affects the metabolism and other organs via the so-called "gut microbiota-organ axes" (e.g., the gut-brain axis, gut-skin axis, gut-lung axis, gut-liver axis) [9]. The intestinal microbiota of healthy, term, vaginally-born, breastfed infants seems to shape the immature immunity of newborns towards developing an immune tolerance. These microbiota-associated 
phenomena (immune system programming and regulatory effects on organ function) were described in a 2018 review paper by Cukrowska [8]). Thus, early intestinal dysbiosis induced by various factors (C-section, formula feeding, antibiotic therapy, smaller families, less contact with nature) may negatively influence the development of immune tolerance by disrupting the mechanisms regulating the balance between Th1 and Th2 cells and finally may activate pro-allergic processes and increased risk of allergy (Figure 1). Allergies are chronic diseases in which the Th2 arm of the adaptive immune response is dominated. The microbiota has a crucial role in generating a balanced immune phenotype that involves maturation of the Th1 cells response and the development of T regulatory (Treg) cells, which suppress the Th2 phenotype [63].

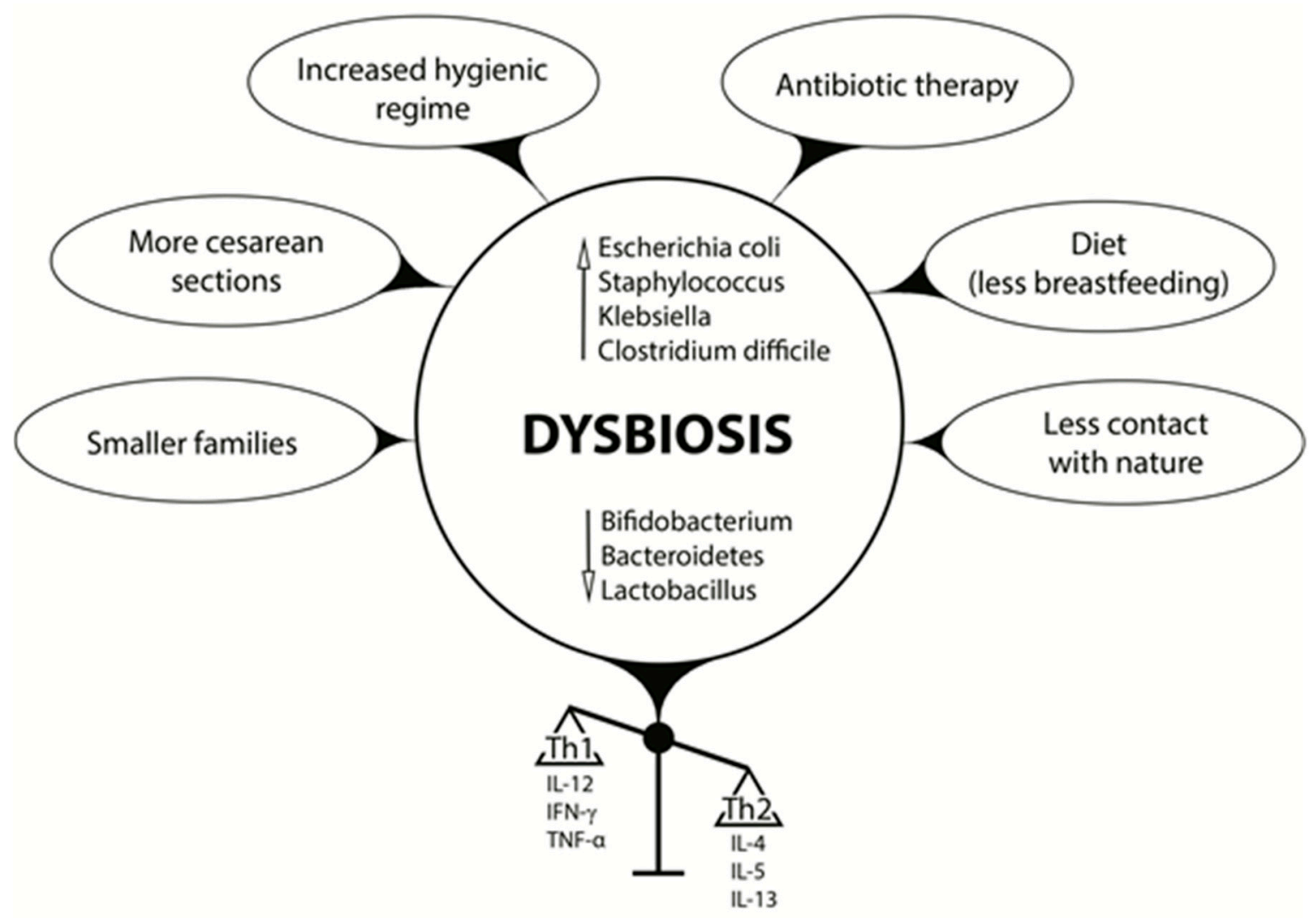

INCREASED RISK OF ALLERGY

Figure 1. Factors affecting the formation of intestinal microbiota that induce dysbiosis and increase the risk of allergy.

Comparisons of the intestinal microbiota of children with allergies with that of healthy children show that children with allergic diseases primarily have a reduced diversity of their gut microbiota and low abundance of Bifidobacterium, Lactobacillus, and Bacteroides [64-74]. Prospective studies suggest that intestinal dysbiosis in early life precedes the development of allergy in older children. Kalliomaki et al. showed that the decrease in the number of Bifidobacterium species and the increase in the number of Clostridium species (a microbiotic profile similar to that in babies born by C-section) observed in 3-week-old newborns was associated with the development of atopy (confirmed by skin-prick tests) within the first year of life [65]. Next-generation sequencing methods and metagenomic approaches showed that infants with immunoglobulin (Ig)E-associated AD have a lower microbiota diversity and a lower diversity of the phylum Bacteroidetes at one month of life, compared with a control group of up to 2-year-old infants without allergic manifestations [66]. Another study demonstrated that decreased bacterial diversity in the 1st year of life was associated with an increased risk of allergic diseases at 6 years of age [67] and an increased risk of asthma at 7 years of age [68]. Furthermore, 
lowering Bifidobacterium and Lactobacillus counts at 1-2 months of age increased the odds of developing an allergy by the age of 5 years [69].

The recently published study by Fieten et al. (2018) aimed to identify the fecal microbial signatures of FA in children with AD [70]. The authors identified six bacterial species which may determine the presence or absence of FA. These included three Bifidobacterium species: Bifidobacterium breve, Bifidobacterium pseudocatenulatum, and Bifidobacterium adolescents. The other three species were: Escherichia coli, Faecalibacterium prausnitzii, and Akkermansia muciniphila. Interestingly, children with FA were observed to have decreased numbers of Bifidobacterium breve, i.e., the species which is typically found in the early infant microbiota and human breast milk.

\section{Intestinal Microbiota, Immunity, and the Development of Immune Tolerance}

During fetal life, the immune system develops towards a pro-allergic Th2 cytokine profile, and its ability to produce Th1 cytokines (e.g., interleukin (IL)-12, interferon (IFN)-gamma) is impaired [71]. In addition, the immune system of newborns is immature, neonatal lymphocytes are referred to as naïve, i.e., never before exposed to external antigens, and the functioning of the intestinal barrier is disturbed due to the lack of secretory IgA, mucus, and microbiota, i.e., the outermost layers of the intestinal surface, which protect against pathogens, allergens, and toxins [72]. Thus, in early life, the baby's immune system is more susceptible to the development of allergic reactions. Gut-colonizing bacteria are among the first antigens that activate the defense mechanisms, help to seal the intestinal epithelial barrier, establish immune tolerance, and modify the body's response to potential allergens [73]. Our recent transmission electron microscopy study demonstrated that the gut microbiota improves the immature intestinal epithelium in germ-free (GF) mice [74]. The study showed the brush border of GF-mouse enterocytes to be arranged irregularly, with decreased numbers of cytoskeletal microfilaments and a lack of elongation into the terminal web. Lactobacillus species, obtained from the stools of healthy infants, significantly improved brush-border architecture and induced an increase in the expression of intraepithelial junction proteins (zonulin, occludin). Other experimental studies showed that colonization of GF piglets or mice with components of the gut microbiota found in healthy infants' stools, such as non-pathogenic Escherichia coli, Bifidobacterium longum, or Lactobacillus strains, induced production of secretory IgA and activated CD4+Fox3+ Treg cells [75-78]. The mechanism of Treg action is associated with the release of cytokines (IL-10 and TGF- $\beta 1$ ) responsible for maintaining homeostasis between Th1 and Th2 cells [79]. Treg activation is one of the basic mechanisms of immune tolerance induction. Disturbed functioning of these cells results in a Th1/Th2 imbalance and produces an abnormal immunological response to external allergens [80].

\section{The Role of Bifidobacterium breve in Anti-Allergic Mechanism Activation-The Importance of Strain Selection}

The genus Bifidobacterium belongs to the phylum Actinobacteria and comprises over 45 species, including Bifidobacterium breve, i.e., the bacterium most commonly isolated from healthy intestines of breastfed infants [12]. This species is also most commonly isolated from human breast milk [54]. In fact, human breast milk may be the main source of Bifidobacterium breve strains that colonize a newborn's intestines shortly after birth [12]. Bifidobacterium breve, which is the main constituent of the intestinal microbiota of healthy newborns, is responsible for the development of intestinal biocenosis as well as for the activation of the immature immune system [81].

The anti-allergic capability of Bifidobacterium breve species was demonstrated in a number of in vitro and experimental animal studies [82,83]. Experimental models of FA to ovalbumin (OVA) in mice showed that out of various strains of Bifidobacterium breve, Bifidobacterium infantis, Bifidobacterium animalis, Lactobacillus plantarum, and Lactobacillus rhamnosus, it was Bifidobacterium breve M-16V that was the most effective in activating an anti-allergic mechanism [83]. In contrast to other evaluated bifidobacteria, only Bifidobacterium breve M-16V (administered orally) significantly inhibited airway reactivity to methacholine and reduced acute allergic skin reactions to OVA. This strain also reduced 
the number of eosinophils in bronchoalveolar lavage fluid, decreased OVA-specific IgE and IgG1 levels in peripheral blood, and inhibited the production of pro-allergic cytokines, such as IL-4 and IL-5 in splenocyte cultures [83]. In vitro analyses demonstrated that although Bifidobacterium breve M-16V suppressed the production of OVA-induced total IgE and IL-4, it activated the secretion of IFN-gamma (but not IL-12) and IL-10 at the same time, affecting the maintenance of the systemic Th1/Th2 balance [82].

\subsection{The Impact of Bifidobacterium breve M-16V on Infant Immunity}

The potential beneficial effects of Bifidobacterium breve M-16V strain on infant health (observed also in pre-term infants) have been recently presented in a review paper by Wong et al. [84].

Pre-clinical experimental studies and clinical trials showed that Bifidobacterium breve M-16V may protect against the development of allergies through the impact on the intestinal microbiota, intestinal epithelial barrier, and immune system. This strain promotes bifidobacterial colonization during early infancy and stimulates secretory IgA production [85]. Clinical studies in premature infants showed that Bifidobacterium breve $\mathrm{M}-16 \mathrm{~V}$ administration for four weeks leads to higher levels of short chain fatty acids (especially acetate) in infant stools. This phenomenon is often associated with an abundance of bifidobacteria, which may improve epithelial-cell barrier function [86]. Studies in an experimental rat model demonstrated a direct activation of immature immunity by Bifidobacterium breve M-16V [87]. Oral supplementation with this strain enhanced the process of naïve T-cell homing to mesenteric lymph nodes and the retention of activated T cells in the intraepithelial compartment, probably via increased expression of integrin $\alpha \mathrm{E} \beta 7$. Administration of Bifidobacterium breve $\mathrm{M}-16 \mathrm{~V}$ to pre-term newborns, initiated several hours after birth, induced a significant increase both in serum TGF- $\beta 1$ levels and expression of TGF- $\beta$ signaling molecule Smad3 [88]. These results suggest that Bifidobacterium breve $\mathrm{M}-16 \mathrm{~V}$ is able to stimulate regulatory TGF- $\beta 1$ produced by Treg cells even in premature newborns. The ability to activate Treg cells is of great importance in pre-term newborns, who are at high risk of developing NEC and late-onset sepsis. Bifidobacterium breve M-16V, colonizing the gut and inducing epithelial barrier maturation, may protect against pathogenic bacteria and their translocation; additionally, this strain is able to induce anti-inflammatory processes, e.g., by increasing IFN-gamma secretion [83]. However, the activation of pro-inflammatory cytokine profile can be actively regulated by suppressive cytokines produced by Treg cells, such as TGF- $\beta 1$ or IL-10 [79]. Another mechanism for the controlled activation of inflammatory processes in premature babies by Bifidobacterium breve may be associated with the modulation of the expression of toll-like receptors (TLRs) located in the gut epithelium. Oral administration of Bifidobacterium breve M-16V to the experimental NEC rats significantly decreased the expression of TLR-4, enhanced the expression of TLR-2, and suppressed pro-inflammatory cytokines, including IL-1 beta, IL- 6 and tumor necrosis factor alpha that resulted from NEC induction [89]. It is known that TLRs are the main receptors for interaction between the gut epithelium and the microbiota that enables development of both the intestinal epithelial barrier and the immune homeostasis [90].

\subsection{Bifidobacterium breve $M-16 V$ and Allergic Diseases}

Several interventional studies suggest that Bifidobacterium breve M-16V may prevent or reduce the severity of allergic conditions, including FA, AD, allergic rhinitis, and asthma [91-93]. The first relevant randomized controlled trial was performed in 2003 and involved 15 bifidobacteria-deficient infants with AD [91]. The authors reported that Bifidobacterium breve M-16V administration was not only effective in improving the severity of allergic symptoms but also significantly increased the number of Bifidobacterium species and decreased the number of total aerobes in the gut microbiota.

The effectiveness of Bifidobacterium breve M-16V in allergy management was also demonstrated when this strain was used as a mixture in combination with Bifidobacterium longum BB536 and Bifidobacterium infantis M-63, i.e., other species that can also be found in breastfed infants [92]. The mixture was administered orally for four weeks in children with seasonal allergic rhinitis as part of a 
randomized double-blind placebo-controlled trial. Del Giudice et al. showed that administration of this mixture reduced the symptoms of pollen-induced IgE-mediated allergic rhinitis and intermittent asthma and improved the quality of life. By contrast, allergic symptoms and the quality of life worsened in the placebo group [92]. Enomoto et al. reported that pre-natal Bifidobacterium breve M-16V and Bifidobacterium longum BB536 supplementation in pregnant women and a subsequent post-natal supplementation in newborns may activate anti-allergic mechanisms of the immature immune system and lower the risk of allergy development in infants [93]. This open trial involved administering a mixture of these two strains to 130 pregnant women, starting one month before delivery, and post-natally to their infants for six months. The control group included mother-infant pairs who did not receive probiotics. The risk of developing AD during the first 18 months of life was significantly reduced in the infants from the probiotic group (OR $=0.231$ (95\% CI 0.084-0.628) and $0.304(0.105-0.892)$ at 10 and 18 months of age, respectively).

\section{Synbiotic Formulas Fortified with Bifidobacterium breve-The Effects on the Intestinal Microbiota and the Role in Allergy Management}

The concept of synbiotics-based on the synergistic actions of probiotics and prebiotics resulting in an optimal composition of the infant gut microbiota-seems to be useful in allergy management in non-breastfed infants. Synbiotic formulas are defined as infant formulas fortified with two ingredients found in human breast milk: prebiotic oligosaccharides and probiotic bacteria [94,95]. Prebiotics are oligosaccharides that provide sustenance for bacteria. Preparations containing galactooligosaccharides (GOS), fructooligosaccharides (FOS), 2'-fukosyllactose, and/or lacto-N-neo-tetraose are examples of commonly used and studied products for infant formula supplementation. The probiotics added to synbiotic formulas are most commonly bacteria (isolated from breast milk and/or healthy infant stools) characterized by experimentally proven immunomodulatory effects.

Molecular analyses have demonstrated that infant-associated Bifidobacterium breve strains express high abundance of genes that are predicted to encode carbohydrate-utilizing enzymes that catabolize sucrose, fructose, lactose, glucose, and galactose [96]. Interestingly, bifidobacteria, including Bifidobacterium breve species, express also genes involved in maltodextrin utilization [96]. Thus, it seems that not only HMOs, lactose or other known prebiotic oligosaccharides can serve as prebiotic substrates for specific Bifidobacterium strains, but also maltodextrin present in formulas intended for premature infants may be utilized by Bifidobacterium breve. However, there are currently no studies that would support this hypothesis, and it should be emphasized that experimental research carried out on a pre-term pig model of spontaneous NEC suggests that the presence of maltodextrin in formula, unlike lactose, may increase the risk of NEC [97].

Chua et al. studied the effects of synbiotic infant formulas on C-section-associated dysbiosis [98]. The study compared the effects of formulas enriched with scGOS/lcFOS and Bifidobacterium breve M-16V, with scGOS/lcFOS alone, and not enriched with any additional bioactive components. The control group consisted of newborns with an optimal microbiota composition due to their vaginal birth and subsequent breastfeeding. Out of all the evaluated formulas, the synbiotic formula showed the most pronounced ameliorating effect on C-section-associated dysbiosis. Newborns fed with synbiotic formula were observed to have an increase in bifidobacteria numbers that started on the 3rd day of life and was sustained for 16 weeks. The amount of bifidobacteria in the experimental group was comparable to that in vaginally-born, breastfed infants during the entire study period. This bifidogenic effect of synbiotic formulas was also confirmed in young children, aged 1-3 years, in whom a 3-month administration of a synbiotic formula resulted in an increase in the number of Bifidobacterium species [99].

These results show that synbiotic formulas may have a beneficial long-term effect (similar to that of breast milk) on the composition of the intestinal microbiota in infants at risk for early dysbiosis, i.e., in newborns born by C-section or children pre-/post-natally exposed to antibiotic therapy. In addition, experimental in vivo studies on a mouse model of allergy showed that administration of 
a synbiotic consisting of Bifidobacterium breve M-16V and GOS/FOS or FOS mixture could protect against the development of cow's milk allergy [100]. Administration of Bifidobacterium breve M-16V in combination with specific $\beta$-lactoglobulin-derived peptides and prebiotic scFOS/lcFOS in mice was shown to prevent the acute allergic skin response and clinical signs of allergy in mice challenged intradermally with whole whey protein. Cytokine analyses conducted in cultures of lymphocytes isolated from the spleen, mesenteric lymph nodes, and the intestinal lamina propria demonstrated that intestinal Th1/Th2 balance was a hallmark of the mechanism underlying the protective effect of the administered mixture [100]. The other pre-clinical study revealed that administration of Bifidobacterium breve $\mathrm{M}-16 \mathrm{~V}$ in combination with non-digestible oligosaccharides could suppress pulmonary airway inflammation in murine OVA-induced asthma models [101]. Synbiotic administration induced a Treg response in the airways by increasing IL-10 and Foxp3 transcription and reducing airway re-modeling. Thus, the presented experimental studies show that dietary supplementation with synbiotics may be effective in prevention of allergy development.

The question remains whether synbiotic formulas containing probiotic strains and prebiotic oligosaccharides may be of importance in immunological and nutritional programming in infants at a higher risk of allergy, on one hand caused by genetic predisposition and on the other by early dysbiosis resulting from C-section or antibiotic treatment.

\section{Conclusions}

Human milk, which contains prebiotic oligosaccharides and probiotic bacteria, is a natural synbiotic, with known beneficial effects on the intestinal microbiota, intestinal barrier, and immune system. Breastfeeding is the optimal source of nutrition and protects against the development of allergies, even in children with a genetic predisposition and C-section- or antibiotic-therapy-induced intestinal dysbiosis. Synbiotic formulas are meant to reflect the composition of human breast milk and protect non-breastfed infants against intestinal dysbiosis and its long-term consequences, such as the development of allergic conditions.

Author Contributions: Conceptualization and supervision by B.C.; original draft preparation by B.C., J.B.B., M.Z., M.K., and E.M.; manuscript review and editing by B.C., M.K., and E.M.; visualization by B.C. and M.K.; project administration by J.B.B; funding acquisition by B.C. All authors have read and agreed to the published version of the manuscript.

Funding: The study was supported by the Children's Memorial Health Institute grant S163/2018 (the principal investigator-B.C.).

Conflicts of Interest: B.C. has served as a speaker for Nutricia, Danone, Bayer, Apotex, Polpharma, and Mead Johnson. Other authors declare no conflicts of interest.

\section{References}

1. Von Mutius, E. The rising trends in asthma and allergic diseases. Clin. Exp. Allergy 1998, 28 (Suppl. 5), 45-49. [CrossRef] [PubMed]

2. Sicherer, S.H.; Sampson, H.A. Food allergy: A review and update on epidemiology, pathogenesis, diagnosis, prevention, and management. J. Allergy Clin. Immunol. 2018, 141, 41-48. [CrossRef] [PubMed]

3. Renz, H.; Holt, P.G.; Inouye, M.; Logan, A.C.; Prescott, S.L.; Sly, P.D. An exposome perspective: Early-life events and immune development in a changing world. J. Allergy Clin. Immunol. 2017, 140, 24-40. [CrossRef] [PubMed]

4. Haahtela, T.; Holgate, S.; Pawankar, R.; Akdis, C.A.; Benjaponpitak, S.; Caraballo, L.; Demain, J.; Portnoy, J.; von Hertzen, L.; WAO Special Committee on Climate Change and Biodiversity. The biodiversity hypothesis and allergic disease: World allergy organization position statement. World Allergy Organ. J. 2013, 6, 3. [CrossRef]

5. Papathoma, E.; Triga, M.; Fouzas, S.; Dimitriou, G. Cesarean section delivery and development of food allergy and atopic dermatitis in early childhood. Pediatr. Allergy Immunol. 2016, 27, 419-523. [CrossRef]

6. Tollånes, M.C.; Moster, D.; Daltveit, A.K.; Irgens, L.M. Cesarean section and risk of severe childhood asthma: A population-based cohort study. J. Pediatr. 2008, 153, 112-116. [CrossRef] 
7. Takiishi, T.; Fenero, C.I.M.; Câmara, N.O.S. Intestinal barrier and gut microbiota: Shaping our immune responses throughout life. Tissue Barriers 2017, 5, e1373208. [CrossRef]

8. Cukrowska, B. Microbial and nutritional programming-the importance of the microbiome and early exposure to potential food allergens in the development of allergies. Nutrients 2018, 10, 1541. [CrossRef]

9. Wopereis, H.; Oozeer, R.; Knipping, K.; Belzer, C.; Knol, J. The first thousand days-Intestinal microbiology of early life: Establishing a symbiosis. Pediatr. Allergy. Immunol. 2014, 25, 428-438. [CrossRef]

10. Aagaard, K.; Ma, J.; Antony, K.M.; Ganu, R.; Petrosino, J.; Versalovic, J. The placenta harbors a unique microbiome. Sci. Transl. Med. 2014, 6, 237ra65. [CrossRef]

11. Collado, M.C.; Rautava, S.; Aakko, J.; Isolauri, E.; Salminen, S. Human gut colonisation may be initiated in utero by distinct microbial communities in the placenta and amniotic fluid. Sci. Rep. 2016, 6, 23129. [CrossRef] [PubMed]

12. Collado, M.C.; Cernada, M.; Baüerl, C.; Vento, M.; Pérez-Martínez, G. Microbial ecology and host-microbiota interactions during early life stages. Gut Microbes 2012, 3, 352-365. [CrossRef] [PubMed]

13. Dominguez-Bello, M.G.; Costello, E.K.; Contreras, M.; Magris, M.; Hidalgo, G.; Fierer, N.; Knight, R. Delivery mode shapes the acquisition and structure of the initial microbiota across multiple body habitats in newborns. Proc. Natl. Acad. Sci. USA 2010, 107, 11971-11975. [CrossRef] [PubMed]

14. Solís, G.; de Los Reyes-Gavilan, C.G.; Fernández, N.; Margolles, A.; Gueimonde, M. Establishment and development of lactic acid bacteria and bifidobacteria microbiota in breast-milk and the infant gut. Anaerobe 2010, 16, 307-310. [CrossRef]

15. Thompson, A.L.; Monteagudo-Mera, A.; Cadenas, M.B.; Lampl, M.L.; Azcarate-Peril, M.A. Milk- and solid-feeding practices and daycare attendance are associated with differences in bacterial diversity, predominant communities, and metabolic and immune function of the infant gut microbiome. Front. Cell. Infect. Microbiol. 2015, 5, 3. [CrossRef]

16. Chong, C.Y.L.; Bloomfield, F.H.; O'Sullivan, J.M. Factors affecting gastrointestinal microbiome development in neonates. Nutrients 2018, 10, 274. [CrossRef] [PubMed]

17. Sandall, J.; Tribe, R.M.; Avery, L.; Mola, G.; Ha Visser, G.; Se Homer, C.; Gibbons, D.; Kelly, N.M.; Powell Kennedy, H.; Kidanto, H.; et al. Short-term and long-term effects of caesarean section on the health of women and children. Lancet 2018, 392, 1349-1357. [CrossRef]

18. Vangay, P.; Ward, T.; Gerber, J.S.; Knights, D. Antibiotics, pediatric dysbiosis, and disease. Cell Host Microbe 2015, 17, 553-564. [CrossRef] [PubMed]

19. Biasucci, G.; Benenati, B.; Morelli, L.; Bessi, E.; Boehm, G. Cesarean delivery may affect the early biodiversity of intestinal bacteria. J. Nutr. 2008, 138, 1796-1800. [CrossRef] [PubMed]

20. Jakobsson, H.E.; Abrahamsson, T.R.; Jenmalm, M.C.; Harris, K.; Quince, C.; Jernberg, C.; Björkstén, B.; Engstrand, L.; Andersson, A.F. Decreased gut microbiota diversity, delayed Bacteroidetes colonisation and reduced Th1 responses in infants delivered by caesarean section. Gut 2014, 63, 559-566. [CrossRef] [PubMed]

21. Zeber-Lubecka, N.; Kulecka, M.; Ambrozkiewicz, F.; Paziewska, A.; Lechowicz, M.; Konopka, E.; Majewska, U.; Borszewska-Kornacka, M.; Mikula, M.; Cukrowska, B.; et al. Effect of Saccharomyces boulardii and mode of delivery on the early development of the gut microbial community in preterm infants. PLoS ONE 2016, 11, e0150306. [CrossRef] [PubMed]

22. Adeyeye, T.E.; Yeung, E.H.; McLain, A.C.; Lin, S.; Lawrence, D.A.; Bell, E.M. Wheeze and food allergies in children born via cesarean section-The upstate KIDS study. Am. J. Epidemiol. 2018, 188, 355-362. [CrossRef] [PubMed]

23. Han, D.H.; Shin, J.M.; An, S.; Kim, J.S.; Kim, D.Y.; Moon, S.; Kim, J.S.; Cho, J.S.; Kim, S.W.; Kim, Y.H.; et al. Long-term Breastfeeding in the Prevention of Allergic Rhinitis: Allergic Rhinitis Cohort Study for Kids (ARCO-Kids Study). Clin. Exp. Otorhinolaryngol. 2019, 12, 301-307. [CrossRef] [PubMed]

24. Magnus, M.C.; Håberg, S.E.; Stigum, H.; Nafstad, P.; London, S.J.; Vangen, S.; Nystad, W. Delivery by cesarean section and early childhood respiratory symptoms and disorders the Norwegian mother and child cohort study. Am. J. Epidemiol. 2011, 174, 1275-1285. [CrossRef] [PubMed]

25. Wu, P.; Feldman, A.S.; Rosas-Salazar, C.; James, K.; Escobar, G.; Gebretsadik, T.; Li, S.X.; Carroll, K.N.; Walsh, E.; Mitchel, E.; et al. Relative importance and additive effects of maternal and infant risk factors on childhood asthma. PLoS ONE 2016, 11, e0151705. [CrossRef] 
26. Azad, M.B.; Konya, T.; Persaud, R.R.; Guttman, D.S.; Chari, R.S.; Field, C.J.; Sears, M.R.; Mandhane, P.J.; Turvey, S.E.; Subbarao, P.; et al. Impact of maternal intrapartum antibiotics, method of birth and breastfeeding on gut microbiota during the first year of life: A prospective cohort study. BJOG 2016, 123, 983-993. [CrossRef]

27. Cassir, N.; Simeoni, U.; La Scola, B. Gut microbiota and the pathogenesis of necrotizing enterocolitis in preterm neonates. Future Microbiol. 2016, 11, 273-292. [CrossRef]

28. McFarland, L.V. Epidemiology, risk factors and treatments for antibiotic-associated diarrhea. Dig. Dis. 1998, 16, 292-307. [CrossRef]

29. Obiakor, C.V.; Tun, H.M.; Bridgman, S.L.; Arrieta, M.C.; Kozyrskyj, A.L. The association between early life antibiotic use and allergic disease in young children: Recent insights and their implications. Expert Rev. Clin. Immunol. 2018, 14, 841-855. [CrossRef]

30. Neuman, H.; Forsythe, P.; Uzan, A.; Avni, O.; Koren, O. Antibiotics in early life: Dysbiosis and the damage done. FEMS. Microbiol. Rev. 2018, 42, 489-499. [CrossRef]

31. Nogacka, A.; Salazar, N.; Suárez, M.; Milani, C.; Arboleya, S.; Solís, G.; Fernández, N.; Alaez, L.; Hernández-Barranco, A.M.; de Los Reyes-Gavilán, C.G.; et al. Impact of intrapartum antimicrobial prophylaxis upon the intestinal microbiota and the prevalence of antibiotic resistance genes in vaginally delivered full-term neonates. Microbiome 2017, 5, 93. [CrossRef] [PubMed]

32. Fouhy, F.; Guinane, C.M.; Hussey, S.; Wall, R.; Ryan, C.A.; Dempsey, E.M.; Murphy, B.; Ross, R.P.; Fitzgerald, G.F.; Stanton, C.; et al. High-throughput sequencing reveals the incomplete, short-term recovery of infant gut microbiota following parenteral antibiotic treatment with ampicillin and gentamicin. Antimicrob. Agents Chemother. 2012, 56, 5811-5820. [CrossRef] [PubMed]

33. Eck, A.; Rutten, N.B.M.M.; Singendonk, M.M.J.; Rijkers, G.T.; Savelkoul, P.H.M.; Meijssen, C.B.; Crijns, C.E.; Oudshoorn, J.H.; Budding, A.E.; Vlieger, A.M. Neonatal microbiota development and the effect of early life antibiotics are determined by two distinct settler types. PLoS ONE 2020, 15, e0228133. [CrossRef] [PubMed]

34. Tanaka, S.; Kobayashi, T.; Songjinda, P.; Tateyama, A.; Tsubouchi, M.; Kiyohara, C.; Shirakawa, T.; Sonomoto, K.; Nakayama, J. Influence of antibiotic exposure in the early postnatal period on the development of intestinal microbiota. FEMS Immunol. Med. Microbiol. 2009, 56, 80-87. [CrossRef]

35. Greenwood, C.; Morrow, A.L.; Lagomarcino, A.J.; Altaye, M.; Taft, D.H.; Yu, Z.; Newburg, D.S.; Ward, D.V.; Schibler, K.R. Early empiric antibiotic use in preterm infants is associated with lower bacterial diversity and higher relative abundance of Enterobacter. J. Pediatr. 2014, 165, 23-29. [CrossRef] [PubMed]

36. Arboleya, S.; Sánchez, B.; Milani, C.; Duranti, S.; Solís, G.; Fernández, N.; de los Reyes-Gavilán, C.G.; Ventura, M.; Margolles, A.; Gueimonde, M. Intestinal microbiota development in preterm neonates and effect of perinatal antibiotics. J. Pediatr. 2015, 166, 538-544. [CrossRef]

37. Arboleya, S.; Sánchez, B.; Solís, G.; Fernández, N.; Suárez, M.; Hernández-Barranco, A.M.; Milani, C.; Margolles, A.; de Los Reyes-Gavilán, C.G.; Ventura, M.; et al. Impact of Prematurity and Perinatal Antibiotics on the Developing Intestinal Microbiota: A Functional Inference Study. Int. J. Mol. Sci. 2016, 17, 649. [CrossRef]

38. Yassour, M.; Vatanen, T.; Siljander, H.; Hämäläinen, A.-M.; Härkönen, T.; Ryhänen, S.J.; Franzosa, E.A.; Vlamakis, H.; Huttenhower, C.; Gevers, D.; et al. Natural history of the infant gut microbiome and impact of antibiotic treatments on strain-level diversity and stability. Sci. Transl. Med. 2016, 8, 343ra81. [CrossRef]

39. Ahmadizar, F.; Vijverberg, S.J.H.; Arets, H.G.M.; de Boer, A.; Lang, J.E.; Garssen, J.; Kraneveld, A.; Maitland-van der Zee, A.H. Early-life antibiotic exposure increases the risk of developing allergic symptoms later in life: A meta-analysis. Allergy 2018, 73, 971-986. [CrossRef]

40. Lapin, B.; Piorkowski, J.; Ownby, D.; Freels, S.; Chavez, N.; Hernandez, E.; Wagner-Cassanova, C.; Pelzel, D.; Vergara, C.; Persky, V. Relationship between prenatal antibiotic use and asthma in at-risk children. Ann. Allergy Asthma Immunol. 2015, 114, 203-207. [CrossRef]

41. Stensballe, L.G.; Simonsen, J.; Jensen, S.M.; Bønnelykke, K.; Bisgaard, H. Use of Antibiotics During Pregnancy Increases the Risk of Asthma in Early Childhood. J. Pediatr. 2013, 162, 832-838. [CrossRef] [PubMed]

42. Yoshida, S.; Ide, K.; Takeuchi, M.; Kawakami, K. Prenatal and early-life antibiotic use and risk of childhood asthma: A retrospective cohort study. Pediatr. Allergy Immunol. 2018, 29, 490-495. [CrossRef] [PubMed]

43. Metsälä, J.; Lundqvist, A.; Virta, L.J.; Kaila, M.; Gissler, M.; Virtanen, S.M. Prenatal and post-natal exposure to antibiotics and risk of asthma in childhood. Clin. Exp. Allergy 2015, 45, 137-145. [CrossRef] [PubMed] 
44. Örtqvist, A.K.; Lundholm, C.; Kieler, H.; Ludvigsson, J.F.; Fall, T.; Ye, W.; Almqvist, C. Antibiotics in fetal and early life and subsequent childhood asthma: Nationwide population based study with sibling analysis. BMJ 2014, 349, g6979. [CrossRef]

45. Kummeling, I.; Stelma, F.F.; Dagnelie, P.C.; Snijders, B.E.; Penders, J.; Huber, M.; van Ree, R.; van den Brandt, P.A.; Thijs, C. Early life exposure to antibiotics and the subsequent development of eczema, wheeze, and allergic sensitization in the first 2 years of life: The KOALA Birth Cohort Study. Pediatrics 2007, 119, e225-e231. [CrossRef]

46. Stromberg Celind, F.; Wennergren, G.; Vasileiadou, S.; Alm, B.; Goksör, E. Antibiotics in the first week of life were associated with atopic asthma at 12 years of age. Acta Paediatr. 2018, 107, 1798-1804. [CrossRef]

47. Ahmadizar, F.; Vijverberg, S.J.H.; Arets, H.G.M.; de Boer, A.; Turner, S.; Devereux, G.; Arabkhazaeli, A.; Soares, P.; Mukhopadhyay, S.; Garssen, J.; et al. Early life antibiotic use and the risk of asthma and asthma exacerbations in children. Pediatr. Allergy Immunol. 2017, 28, 430-437. [CrossRef]

48. Andreas, N.J.; Kampmann, B.; Mehring Le-Doare, K. Human breast milk: A review on its composition and bioactivity. Early Hum. Dev. 2015, 91, 629-635. [CrossRef]

49. Chen, X. Human Milk Oligosaccharides (HMOS): Structure, function, and enzyme-catalyzed synthesis. Adv. Carbohydr. Chem. Biochem. 2015, 72, 113-190. [CrossRef]

50. Asakuma, S.; Hatakeyama, E.; Urashima, T.; Yoshida, E.; Katayama, T.; Yamamoto, K.; Kumagai, H.; Ashida, H.; Hirose, J.; Kitaoka, M. Physiology of consumption of human milk oligosaccharides by infant gutassociated bifidobacteria. J. Biol. Chem. 2011, 286, 34583-34592. [CrossRef]

51. Jost, T.; Lacroix, C.; Braegger, C.; Chassard, C. Impact of human milk bacteria and oligosaccharides on neonatal gut microbiota establishment and gut health. Nutr. Rev. 2015, 73, 426-437. [CrossRef] [PubMed]

52. Fernández, L.; Langa, S.; Martín, V.; Rogriguez, J.M. The microbiota of human milk in healthy women. Cell Mol. Biol. 2013, 59, 31-42.

53. Martín, R.; Jiménez, E.; Heilig, H.; Fernández, L.; Marín, M.L.; Zoetendal, E.G.; Rodríguez, J.M. Isolation of bifidobacteria from breast milk and assessment of the bifidobacterial population by PCR-denaturing gradient gel electrophoresis and quantitative real-time PCR. Appl. Environ. Microbiol. 2009, 75, 965-969. [CrossRef]

54. Khodayar-Pardo, P.; Mira-Pascual, L.; Collado, M.C.; Martínez-Costa, C. Impact of lactation stage, gestational age and mode of delivery on breast milk microbiota. J. Perinatol. 2014, 34, 599-605. [CrossRef] [PubMed]

55. Cabrera-Rubio, R.; Mira-Pascual, L.; Mira, A.; Collado, M.C. Impact of mode of delivery on the milk microbiota composition of healthy women. J. Dev. Orig. Health Dis. 2016, 7, 54-60. [CrossRef] [PubMed]

56. Collado, M.C.; Laitinen, K.; Salminen, S.; Isolauri, E. Maternal weight and excessive weight gain during pregnancy modify the immunomodulatory potential of breast milk. Pediatr. Res. 2012, 72, 77-85. [CrossRef] [PubMed]

57. Soto, A.; Martín, V.; Jiménez, E.; Rodríguez, J.M.; Fernández, L. Lactobacilli and bifidobacteria in human breast milk: Influence of antibiotherapy and other host and clinical factors. J. Pediatr. Gastroenterol. Nutr. 2014, 59, 78-88. [CrossRef]

58. Grönlund, M.M.; Gueimonde, M.; Laitinen, K.; Kociubinski, G.; Grönroos, T.; Salminen, S.; Isolauri, E. Maternal breast-milk and intestinal bifidobacteria guide the compositional development of the Bifidobacterium microbiota in infants at risk of allergic disease. Clin. Exp. Allergy 2007, 37, 1764-1772. [CrossRef]

59. Olivares, M.; Albrecht, S.; De Palma, G.; Ferrer, M.D.; Castillejo, G.; Schols, H.A.; Sanz, Y. Human milk composition differs in healthy mothers and mothers with celiac disease. Eur. J. Nutr. 2015, 54, 119-128. [CrossRef]

60. Kramer, M.S. Breastfeeding and allergy: The evidence. Ann. Nutr. Metab. 2011, 59, 20-26. [CrossRef]

61. Klopp, A.; Vehling, L.; Becker, A.B.; Subbarao, P.; Mandhane, P.J.; Turvey, S.E.; Lefebvre, D.L.; Sears, M.R.; Daley, D.; Silverman, F.; et al. Modes of Infant Feeding and the Risk of Childhood Asthma: A Prospective Birth Cohort Study. J. Pediatr. 2017, 190, 192-199. [CrossRef] [PubMed]

62. Chu, S.; Chen, Q.; Chen, Y.; Bao, Y.; Wu, M.; Zhang, J. Cesarean section without medical indication and risk of childhood asthma, and attenuation by breastfeeding. PLoS ONE 2017, 12, e0184920. [CrossRef] [PubMed]

63. Pascal, M.; Perez-Gordo, M.; Caballero, T.; Escribese, M.M.; Lopez Longo, M.N.; Luengo, O.; Manso, L.; Matheu, V.; Seoane, E.; Zamorano, M.; et al. Microbiome and Allergic Diseases. Front. Immunol. 2018, 9 , 1584. [CrossRef] [PubMed] 
64. Bjorksten, B.; Naaber, P.; Sepp, E.; Mikelasaar, M. The intestinal microflora in allergic Estonian and Swedish 2-year-old children. Clin. Exp. Allergy 1999, 29, 342-346. [CrossRef] [PubMed]

65. Kalliomäki, M.; Kirjavainen, P.; Eerola, E.; Kero, P.; Salminen, S.; Isolauri, E. Distinct patterns of neonatal gut microflora in infants in whom atopy was not developing. J. Allergy Clin. Immunol. 2001, 107, 129-134. [CrossRef]

66. Abrahamsson, T.R.; Jakobsson, H.E.; Andersson, A.F.; Björkstén, B.; Engstrand, L.; Jenmalm, M.C. Low diversity of the gut microbiota in infants with atopic eczema. J. Allergy Clin. Immunol. 2012, 129, 434-440. [CrossRef]

67. Bisgaard, H.; Li, N.; Bonnelykke, K.; Chawes, B.L.; Skov, T.; Paludan-Müller, G.; Stokholm, J.; Smith, B.; Krogfelt, K.A. Reduced diversity of the intestinal microbiota during infancy is associated with increased risk of allergic disease at school age. J. Allergy Clin. Immunol. 2011, 128, 646-652. [CrossRef]

68. Abrahamsson, T.R.; Jakobsson, H.E.; Andersson, A.F.; Björkstén, B.; Engstrand, L.; Jenmalm, M.C. Low gut microbiota diversity in early infancy precedes asthma at school age. Clin. Exp. Allergy 2014, 44, 842-850. [CrossRef]

69. Sjögren, Y.M.; Jenmalm, M.C.; Böttcher, M.F.; Björkstén, B.; Sverremark-Ekström, E. Altered early infant gut microbiota in children developing allergy up to 5 years of age. Clin. Exp. Allergy 2009, 39, 518-526. [CrossRef]

70. Fieten, K.B.; Totté, J.E.E.; Levin, E.; Reyman, M.; Meijer, Y.; Knulst, A.; Schuren, F.; Pasmans, S.G.M.A. Fecal Microbiome and Food Allergy in Pediatric Atopic Dermatitis: A Cross-Sectional Pilot Study. Int. Arch. Allergy Immunol. 2018, 175, 77-84. [CrossRef]

71. Brugman, S.; Perdijk, O.; van Neerven, R.J.; Savelkoul, H.F. Mucosal immune development in early life: Setting the stage. Arch. Immunol. Ther. Exp. 2015, 63, 251-268. [CrossRef] [PubMed]

72. Olin, A.; Henckel, E.; Chen, Y.; Lakshmikanth, T.; Pou, C.; Mikes, J.; Gustafsson, A.; Bernhardsson, A.K.; Zhang, C.; Bohlin, K.; et al. Stereotypic immune system development in newborn children. Cell 2018, 174, 1277-1292. [CrossRef] [PubMed]

73. Tlaskalová-Hogenová, H.; Stepánková, R.; Hudcovic, T.; Tucková, L.; Cukrowska, B.; Lodinová-Zádníková, R.; Kozáková, H.; Rossmann, P.; Bártová, J.; Sokol, D.; et al. Commensal Bacteria (Normal Microflora), Mucosal Immunity and Chronic Inflammatory and Autoimmune Diseases. Immunol. Lett. 2004, 93, 97-108. [CrossRef] [PubMed]

74. Kozakova, H.; Schwarzer, M.; Tuckova, L.; Srutkova, D.; Czarnowska, E.; Rosiak, I.; Hudcovic, T.; Schabussova, I.; Hermanova, P.; Zakostelska, Z.; et al. Colonization of Germ-Free Mice with a Mixture of Three Lactobacillus Strains Enhances the Integrity of Gut Mucosa and Ameliorates Allergic Sensitization. Cell. Mol. Immunol. 2016, 13, 251-262. [CrossRef]

75. Cukrowska, B.; Kozakova, H.; Rehakova, Z.; Sinkora, J.; Tlaskalova-Hogenova, H. Specific Antibody and Immunoglobulin Responses after Intestinal Colonization of Germ-Free Piglets with Non-Pathogenic Escherichia coli O86. Immunobiology 2001, 204, 425-433. [CrossRef]

76. Zwicker, C.; Sarate, P.; Drinić, M.; Ambroz, K.; Korb, E.; Smole, U.; Köhler, C.; Wilson, M.S.; Kozakova, H.; Sebo, P.; et al. Prophylactic and therapeutic inhibition of allergic airway inflammation by probiotic Escherichia coli O83. J. Allergy Clin. Immunol. 2018, 142, 1987-1990. [CrossRef]

77. Schwarzer, M.; Repa, A.; Daniel, C.; Schabussova, I.; Hrncir, T.; Pot, B.; Stepankova, R.; Hudcovic, T.; Pollak, A.; Tlaskalova-Hogenova, H.; et al. Neonatal colonization of mice with Lactobacillus plantarum producing the aeroallergen Bet $\mathrm{v} 1$ biases towards Th1 and T-regulatory responses upon systemic sensitization. Allergy 2011, 66, 368-375. [CrossRef]

78. Schwarzer, M.; Srutkova, D.; Schabussova, I.; Hudcovic, T.; Wiedermann, U.; Kozakova, H. Neonatal colonization of germ-free mice with Bifidobacterium longum prevents allergic sensitization to major birch pollen allergen Bet v 1. Vaccine 2013, 31, 5405-5412. [CrossRef]

79. Akdis, C.A.; Akdis, M. Mechanisms of immune tolerance to allergens: Role of IL-10 and Tregs. J. Clin. Investig. 2014, 124, 4678-4680. [CrossRef]

80. Satitsuksanoa, P.; Jansen, K.; Głobińska, A.; van de Veen, W.; Akdis, M. Regulatory immune mechanisms in tolerance to food allergy. Front. Immunol. 2018, 9, 2939. [CrossRef]

81. Bozzi Cionci, N.; Baffoni, L.; Gaggìa, F.; Di Gioia, D. Therapeutic microbiology: The role of Bifidobacterium breve as food supplement for the prevention/treatment of paediatric diseases. Nutrients 2018, 10, 1723. [CrossRef] [PubMed] 
82. Inoue, Y.; Iwabuchi, N.; Xiao, J.Z.; Yaeshima, T.; Iwatsuki, K. Suppressive effects of Bifidobacterium breve strain M-16V on T-helper type 2 immune responses in a murine model. Biol. Pharm. Bull. 2009, 32, 760-763. [CrossRef] [PubMed]

83. Hougee, S.; Vriesema, A.J.M.; Wijering, S.C.; Knippels, L.M.J.; Folkerts, G.; Nijkamp, F.P.; Knol, J.; Garssen, J. Oral treatment with probiotics reduces allergic symptoms in ovalbumin-sensitized mice: A bacterial strain comparative study. Int. Arch. Allergy Immunol. 2010, 151, 107-117. [CrossRef] [PubMed]

84. Wong, C.B.; Iwabuchi, N.; Xiao, J.Z. Exploring the Science behind Bifidobacterium breve M-16V in infant health. Nutrients 2019, 11, 1724. [CrossRef] [PubMed]

85. Rigo-Adrover, M.D.M.; Franch, À.; Castell, M.; Pérez-Cano, F.J. Preclinical immunomodulation by the probiotic Bifidobacterium breve M-16V in early life. PLoS ONE 2016, 11, e0166082. [CrossRef]

86. Wang, C.; Shoji, H.; Sato, H.; Nagata, S.; Ohtsuka, Y.; Shimizu, T.; Yamashiro, Y. Effects of oral administration of Bifidobacterium breve on fecal lactic acid and short-chain fatty acids in low birth weight infants. J. Pediatr. Gastroenterol. Nutr. 2007, 44, 252-257. [CrossRef]

87. Ohtsuka, Y.; Ikegami, T.; Izumi, H.; Namura, M.; Ikeda, T.; Ikuse, T.; Baba, Y.; Kudo, T.; Suzuki, R.; Shimizu, T. Effects of Bifidobacterium breve on inflammatory gene expression in neonatal and weaning rat intestine. Pediatr. Res. 2012, 71, 46-53. [CrossRef]

88. Fujii, T.; Ohtsuka, Y.; Lee, T.; Kudo, T.; Shoji, H.; Sato, H.; Nagata, S.; Shimizu, T.; Yamashiro, Y. Bifidobacterium breve enhances transforming growth factor $\beta 1$ signaling by regulating smad7 expression in preterm infants. J. Pediatr. Gastroenterol. Nutr. 2006, 43, 83-88. [CrossRef]

89. Satoh, T.; Izumi, H.; Iwabuchi, N.; Odamaki, T.; Namba, K.; Abe, F.; Xiao, J.Z. Bifidobacterium breve prevents necrotising enterocolitis by suppressing inflammatory responses in a preterm rat model. Benef. Microbes 2016, 7, 75-82. [CrossRef]

90. Rakoff-Nahoum, S.; Paglino, J.; Eslami-Varzaneh, F.; Edberg, S.; Medzhitov, R. Recognition of commensal microflora by toll-like receptors is required for intestinal homeostasis. Cell 2004, 118, 229-241. [CrossRef]

91. Hattori, K.; Yamamoto, A.; Sasai, M.; Taniuchi, S.; Kojima, T.; Kobayashi, Y.; Iwamoto, H.; Namba, K.; Yaeshima, T. Effects of administration of bifidobacteria on fecal microflora and clinical symptoms in infants with atopic dermatitis. Arerugi 2003, 52, 20-30. [PubMed]

92. Del Giudice, M.M.; Indolfi, C.; Capasso, M.; Maiello, N.; Decimo, F.; Ciprandi, G. Bifidobacterium mixture (B longum BB536, B infantis M-63, B breve M-16V) treatment in children with seasonal allergic rhinitis and intermittent asthma. Ital. J. Pediatr. 2017, 43, 25. [CrossRef] [PubMed]

93. Enomoto, T.; Sowa, M.; Nishimori, K.; Shimazu, S.; Yoshida, A.; Yamada, K.; Furukawa, F.; Nakagawa, T.; Yanagisawa, N.; Iwabuchi, N.; et al. Effects of Bifidobacterial Supplementation to Pregnant Women and Infants in the Prevention of Allergy Development in Infants and on Fecal Microbiota. Allergol. Int. 2014, 63, 575-585. [CrossRef] [PubMed]

94. Kolida, S.; Gibson, G.R. Synbiotics in health and disease. Annu. Rev. Food Sci. Technol. 2011, 2, $373-393$. [CrossRef]

95. Miqdady, M.; Al Mistarihi, J.; Azaz, A.; Rawat, D. Prebiotics in the infant microbiome: The past, present, and future. Pediatr. Gastroenterol. Hepatol. Nutr. 2020, 23, 1-14. [CrossRef]

96. Khoroshkin, M.S.; Leyn, S.S.; Van Sinderen, D.; Rodionov, D.A. Transcriptional regulation of carbohydrate utilization pathways in the Bifidobacterium genus. Front. Microbiol. 2016, 7, 120. [CrossRef]

97. Buddington, R.K.; Davis, S.L.; Buddington, K.K. The risk of necrotizing enterocolitis differs among preterm pigs fed formulas with either lactose or maltodextrin. J. Pediatr. Gastroenterol. Nutr. 2018, 66, e61-e66. [CrossRef]

98. Chua, M.C.; Ben-Amor, K.; Lay, C.; Neo, A.G.E.; Chiang, W.C.; Rao, R.; Chew, C.; Chaithongwongwatthana, S.; Khemapech, N.; Knol, J.; et al. Effect of synbiotic on the gut microbiota of cesarean delivered infants: A randomized, double-blind, multicenter study. J. Pediatr. Gastroenterol. Nutr. 2017, 65, 102-106. [CrossRef]

99. Kosuwon, P.; Lao-Araya, M.; Uthaisangsook, S.; Lay, C.; Bindels, J.; Knol, J.; Chatchatee, P. A Synbiotic Mixture of scGOS/lcFOS and Bifidobacterium breve M-16V Increases Faecal Bifidobacterium in Healthy Young Children. Benef. Microbes 2018, 9, 541-552. [CrossRef] 
100. Kostadinova, A.I.; Meulenbroek, L.A.; van Esch, B.C.; Hofman, G.A.; Garssen, J.; Willemsen, L.E.; Knippels, L.M. A specific mixture of fructo-oligosaccharides and Bifidobacterium breve $\mathrm{m}-16 \mathrm{v}$ facilitates partial non-responsiveness to whey protein in mice orally exposed to $\beta$-lactoglobulin-derived peptides. Front. Immunol. 2017, 7, 673. [CrossRef]

101. Sagar, S.; Vos, A.P.; Morgan, M.E.; Garssen, J.; Georgiou, N.A.; Boon, L.; Kraneveld, A.D.; Folkerts, G. The combination of Bifidobacterium breve with non-digestible oligosaccharides suppresses airway inflammation in a murine model for chronic asthma. Biochim. Biophys. Acta 2014, 1842, 573-583. [CrossRef] [PubMed]

(C) 2020 by the authors. Licensee MDPI, Basel, Switzerland. This article is an open access article distributed under the terms and conditions of the Creative Commons Attribution (CC BY) license (http://creativecommons.org/licenses/by/4.0/). 